ISSN No. 0974-035X

An indexed refereed \& peer-reviewed journal of higher education

Towards Excellence

UGC-HUMAN RESOURCE DEVELOPMENT CENTRE

Gujarat University, Ahmedabad-380009, Gujarat, India

\title{
RISK-RETURN TRADEOFFS IN INDIAN STOCK MARKET: EVIDENCE FROM GARCH MODEL APPROACH
}

\author{
Dr. Ritesh Patel
}

\begin{abstract}
The objective is to examine the risk-return tradeoff in the Indian stock market. The sample period of study is from January 4, 2000 to December 31, 2020. The empirical results shows existence of risk-return tradeoff in the BSE. A positive risk-return tradeoff is found for monthly \& annual return series. The market has weak risk-return relationship in daily return series. The CGARCH $(1,1)$ captures the asymmetric volatility effect for all the different frequency based returns. The study has implications for the investors. The riskreturn relationship is stronger and significant in longer duration of investment. The market gives higher return when there is a high risk.
\end{abstract}

Key Words: Risk-return tradeoff, GARCH Model, BSE, Volatility, Stock returns JEL Classification code: C22, G11, G12

\section{Introduction}

The Investment decision of the Investor is mainly depend on the risk and return of the stock. The risk and return are essentials to apply the Capital assets pricing model. Merton's (1973) Intertemporal Capital Assets Pricing Model (ICAPM) is widely used in many studies to predict the risk-return tradeoff. Some past studies have applied the ARIMA and conditional market volatility for evaluating the risk-return tradeoff. However, all these models have some limitations. Hence, the present study is focusing on evaluating the risk-return tradeoff using GARCH model.

Many past studied have focus on the dynamic relationship of risk-return for the developed markets, whereas there is lack of such studies for the emerging markets, including India. Hence, the present study focuses on the examining the risk-return tradeoff for the Indian stock market using GARCH model. Further, this study also focus on examining the risk return relationship for longer sample with daily, monthly, and annual return series.

The rest of the paper is structured as follows. Section 2 covers the literature review of past studies. The empirical framework is shown in Section 3. The data analysis is covered in section 4 . The section 5 shows the conclusion and implications of the study.

\section{Literature review}




\section{Ritesh Patel / Page 556-566}

\section{- Review of Past studies}

The risk-return relationship is one of the basic concept in the financial market studies. The risk-return relationship determines the efficient frontier. When the market portfolio is on mean-variance efficient frontier, there is an exact linear relationship in return and risk, Roll and Ross (1994). In past, many studies have been conducted to evaluate the risk-return relationship among the markets using various empirical frameworks. Using the Sharpe-Lintner-Black model, Pettengill et al. (1995) proves the strong and positive relation in risk and return. Nelson (1991) have reported negative risk-return relationship.

Many studies conducted in the past have found positive risk-return relationship. Using the GARCH model, Bali et al. (2009) studied the NYSE market covering a period from 1963 to 2004 and revealed positive and significant risk-return relationship. Using threefactor multiple regression, Bagchi (2012) found positive and significant risk-return relationship for the Indian market. The study also found stronger relationship of riskreturn in the longer period as compare to shorter period. Using the GARCH Model, Cheng and Jahan-Parvar (2014) studied the 14 Pacific basin markets and found positive and significant risk-return relationship. Terregrossa and Eraslan (2016) found systematic relationship between risk and portfolio return. Using Fama-French Three-Factor model with momentum, $\mathrm{Wu}$ (2018) found positive risk-return relationship for three leading stock markets of US from 2003 to 2014.

Some past studies found negative risk-return relationship. Conrad (2013) found that the return of individual security is strongly related with the skewness and kurtosis. The study found negative relationship among the volatility and stock return. Aslanidis et al. (2016) found negative risk-return relationship for 13 European markets from 1986 to 2012.

\section{- Research Gap}

The past studies were conducted in US, Developed and European markets using the CAPM and GARCH model. Further, the past studies were done using annual data. However, the past studies have not focused Indian stock market. Hence, in order to fulfill following gaps the present study is performed. First the study is performed to examine the risk-return relationship in the Indian stock market. Second, the study is conducted using GARCH-M, EGARCH-M and GARCH $(1,1)$ models to get the robust results. Third, the present study is performed based on daily, monthly, and annual data.

\section{Research Methodology}

The objective of the study is to explore the risk-return relationship in the Indian stock market. The study also aims to examine the risk-return tradeoff for different frequency data. The study is performed on the Bombay Stock Exchange covering a sample period from January 4, 2000 to December 31, 2020. This paper studies the risk-return tradeoff using daily, monthly, and annual data. It has been found that the market has observed some bank holidays and as a result, the market does not produce any information on those 


\section{Ritesh Patel / Page 556-566}

days. In such cases, the information of the previous-day is used to get the information about the holiday.

The non-observability of the conditional variance is the main difficulty in the measurement of the risk-return tradeoff. Hence, the GARCH model are used by applying the past returns. The GARCH-M model was developed by Bollerslev et al. (1988). The GARCH-M model provides the framework to measure the risk-return tradeoff by connecting the conditional variance (risk) to conditional mean (return). The GARCH-M model has some limitations, which makes the model weak. Hence, EGARCH Model was propose by the Nelson (1991) with leverage effect of "good" or "bad" news on the stock returns, which is indicated by $\theta$. Glosen et al. (1993) gave the GJR-GARCH (TGARCH) model for the risk-return relationship tradeoff. However, as compare to all other models, the EGARCH model is superior in measuring the risk-return tradeoff as the EGARCH has log form of conditional variance, which ensures the non-negativity of the model. The Superiority of the EGRACH model over the other models is supported by past studies of Hamilton (1994). Superior measure of the conditional volatility may produce more accurate risk-return tradeoff (Ghysels et al., 2005). In order to explore the risk-return relationship in better way, Engle and lee (1999) have proposed a new variant of CGARCH Model. The CGARCH $(1,1)$ model has short-run component of variance $\left(\sigma^{2}{ }^{2}-q_{t}\right)$ and longrun component of variance $\left(\mathrm{q}_{\mathrm{t}}\right)$. The CGARCH parameter $\varsigma$ captures the symmetric effects of "good" or "bad" news on the stock returns in the short-run and the short-run leverage effects. The study is performed on the BSE using the GARCH-M, EGARCH-M and CGARCH $(1,1)$ model.

\section{Empirical Analysis}

\section{- Descriptive statistics}

Table 1

Descriptive statistics

\begin{tabular}{|l|c|c|c|}
\hline Particulars & Daily & Monthly & Annual \\
\hline Mean & 0.05093 & 1.06726 & 17.4542 \\
\hline Median & 0.09079 & 1.03577 & 13.0799 \\
\hline Maximum & 17.3393 & 28.2551 & 81.0329 \\
\hline Minimum & -11.1386 & -23.8901 & -52.4458 \\
\hline Std. Dev. & 1.428564 & 6.403330 & 32.4720 \\
\hline Skewness & 0.027035 & 0.142407 & 0.27088 \\
\hline Kurtosis & 11.89676 & 4.801945 & 3.989099 \\
\hline Observations & 5003 & 241 & 19 \\
\hline
\end{tabular}

Source: Author's calculation

Table 1 shows the descriptive statistics for the daily, monthly, and annual data. The mean return on daily basis was 0.05 percent with standard deviation (risk) of 1.42 percent. The monthly return is 1.06 percent with standard deviation of 6.40 percent. The annual return and standard deviation is 17.45 percent and 32.47 percent, respectively. It is observed that 


\section{Ritesh Patel / Page 556-566}

the return is increasing with the increase in the risk. Further, it is observed that longer the duration, higher the risk and return. The increasing trend of risk-return proves the exitance of financial theory that higher the risk higher the return. The skewness is positive for all the sample period, which further reveals the higher probability to earn positive returns in the market. The kurtosis value for all the sample period is more than 3 , which is suitable for further study.

\section{- Unit root test}

Table 2

Unit root test

\begin{tabular}{|l|l|l|l|l|}
\hline \multirow{2}{*}{ Duration } & \multicolumn{2}{|l|}{ Level } & \multicolumn{2}{l|}{ First Difference } \\
\cline { 2 - 5 } & ADF & PP & ADF & PP \\
\hline Daily & -2.723 & -2.747 & $-85.325^{*}$ & $-101.502^{*}$ \\
\hline Monthly & -2.581 & -2.507 & $-125.105^{*}$ & $-125.892^{*}$ \\
\hline Annual & -1.882 & -1.895 & $-59.774^{*}$ & $-59.788^{*}$ \\
\hline
\end{tabular}

Notes: *Significant at 1 percent level.

Source: Author's calculation

Table 2 shows the Unit root test results for BSE market with respect to different frequency returns. In order to apply the GARCH model, the data need to be stationary (Gujarati, 2013). Here, the stationarity of the data is checked using the ADF test (Dickey, 1979, Dickey, 1986) and the PP test (Phillips, 1988) test. The Unit Root Tests are done in the EViews 9 software. The outcome of the unit root test revealed that $\mathrm{H} 0$ is fail to be rejected at 1 percent significance level. However, the test can be rejected at the first difference. Overall, the data is found suitable to apply the GARCH model.

\section{- Estimation of risk-return tradeoff}

The risk-return tradeoff is estimated using the daily, monthly, and annual returns. The GARCH-M, EGARCH-M and CGARCH $(1,1)$ model are used to estimate the risk-return tradeoff. The CGARCH $(1,1)$ is superior as compare to other models in estimating the tradeoff (Bollerslev et al., 1992). The Estimation is performed by the method of maximum likelihood. The lag and constant in the mean equation are determine by the Akaike information criterion (AIC). The results of the estimation of tradeoff using different frequency set are reported below.

\section{○ Daily return based estimation of risk-return tradeoff}

Table 3

BSE Risk-return tradeoff estimation on Daily return

\begin{tabular}{|c|c|c|c|}
\hline Particulars & GARCH-M & EGARCH-M & CGARCH (1,1) \\
\hline Mean equation & $0.0221^{* *}$ & $0.03269^{* *}$ & $0.04841^{* *}$ \\
\hline
\end{tabular}


Towards Excellence: An Indexed, Refereed \& Peer Reviewed Journal of Higher Education / Dr.

Ritesh Patel / Page 556-566

\begin{tabular}{|c|c|c|c|}
\hline $\mathrm{C}$ & $(-1.51)$ & $(-2.68)$ & $(-3.12)$ \\
\hline$\theta_{1}$ & $\begin{array}{c}0.1489 * \\
(11.89)\end{array}$ & $\begin{array}{c}0.1508^{*} \\
(11.96)\end{array}$ & $\begin{array}{c}0.1527^{*} \\
(12.51)\end{array}$ \\
\hline$\theta_{2}$ & $\begin{array}{c}-0.04587 * \\
(-2.67)\end{array}$ & $\begin{array}{c}-0.04985^{*} \\
(-2.88)\end{array}$ & $\begin{array}{c}-0.04999 * \\
(-2.94)\end{array}$ \\
\hline$\theta_{3}$ & $\begin{array}{c}0.0059^{*} \\
(4.88)\end{array}$ & $\begin{array}{c}0.00579^{*} \\
(4.97)\end{array}$ & $\begin{array}{c}0.00695^{*} \\
(4.12)\end{array}$ \\
\hline$\lambda$ & $\begin{array}{l}0.0055 \\
(1.22)\end{array}$ & $\begin{array}{c}0.0087 \\
(1.31)\end{array}$ & $\begin{array}{c}0.0088 \\
(1.34)\end{array}$ \\
\hline \multicolumn{4}{|l|}{ Variance Equation } \\
\hline$\alpha_{0}$ & $\begin{array}{c}0.000125^{*} \\
(2.89)\end{array}$ & $\begin{array}{c}0.00549 * * \\
(2.51)\end{array}$ & $\begin{array}{c}0.00557 * * \\
(2.98)\end{array}$ \\
\hline$\alpha_{1}$ & $\begin{array}{c}0.2853 * \\
(3.99)\end{array}$ & $\begin{array}{c}0.3257 * \\
(6.01)\end{array}$ & $\begin{array}{c}0.1478^{*} \\
(2.89)\end{array}$ \\
\hline$\beta_{1}$ & $\begin{array}{c}0.82469 * \\
(15.81)\end{array}$ & $\begin{array}{c}0.85269 * * \\
(22.04)\end{array}$ & $\begin{array}{c}0.9250 * * * \\
(25.78)\end{array}$ \\
\hline$\gamma_{1}$ & $\begin{array}{c}0.0045^{*} \\
(1.59)\end{array}$ & $\begin{array}{c}0.00542^{*} \\
(1.82)\end{array}$ & $\begin{array}{c}0.04575^{* *} \\
\quad(1.58)\end{array}$ \\
\hline Log Likelihood & 1748.95 & 1755.69 & 1756.14 \\
\hline Ljung-Box Q (12) & $\begin{array}{c}75.478 * * \\
(0.0758)\end{array}$ & $\begin{array}{c}81.056 * * \\
(0.0659)\end{array}$ & $\begin{array}{l}84.529 * * \\
(0.0625)\end{array}$ \\
\hline Ljung-Box $Q^{2}(12)$ & $\begin{array}{c}0.489 \\
(0.0754)\end{array}$ & $\begin{array}{c}0.685 \\
(0.0654)\end{array}$ & $\begin{array}{c}0.797 \\
(0.0621)\end{array}$ \\
\hline
\end{tabular}

Source: Author's calculation

Notes: $* * *, * * *$ indicates significance level at 1,5 and 10 percent, respectively.

Table 3 shows the BSE Risk-return tradeoff estimation on Daily return using the GARCH-M, EGARCH-M and CGARCH $(1,1)$ model. The conditional volatility is positive but statistically insignificant for all the models, which reveals weak relationship in risk-return for the market. There are three lags in the mean equation, which are statistically significant at 1 percent level. It further reveals that the past values have significant impact on the current returns.

In the variance equation, the value of $\gamma_{1}$ is significant at 5 percent for the GARCH-M and EGARCH-M model. However, the value of $\gamma_{1}$ is significant at 1 percent for the CGARCH-M Model. It further enhances that the return shows the unequal effect of positive and negative innovations. The result of Ljung-Box statistics found that in 12-th order the serial autocorrelations are found significant for all the models. Further, the results of Log Likelihood is highest in the CGARCH-M model as compare to GARCH$\mathrm{M}$ and EGARCH-M models, which found that the data fits best in the CGARCH-M as compare to others. Overall, there is weak risk-return relationship in the BSE market for daily data return series. 
Towards Excellence: An Indexed, Refereed \& Peer Reviewed Journal of Higher Education / Dr. Ritesh Patel / Page 556-566

$\circ$ Monthly return based estimation of risk-return tradeoff

Table 4

BSE Risk-return tradeoff estimation on monthly return

\begin{tabular}{|c|c|c|c|}
\hline Particulars & GARCH-M & EGARCH-M & CGARCH $(1,1)$ \\
\hline $\begin{array}{l}\text { Mean equation } \\
\mathrm{C}\end{array}$ & $\begin{array}{c}0.0241 * * \\
(-1.46)\end{array}$ & $\begin{array}{c}0.0271 * * \\
(-2.14)\end{array}$ & $\begin{array}{c}0.0391 * * \\
(-2.01)\end{array}$ \\
\hline$\theta_{1}$ & $\begin{array}{c}0.0125^{*} \\
(9.01)\end{array}$ & $\begin{array}{c}0.0257^{*} \\
(9.87)\end{array}$ & $\begin{array}{l}0.0398^{*} \\
(10.01)\end{array}$ \\
\hline$\theta_{2}$ & $\begin{array}{c}-0.0941 * \\
(-1.73)\end{array}$ & $\begin{array}{c}-0.0570^{*} \\
(-2.09)\end{array}$ & $\begin{array}{c}-0.0609 * \\
(-2.39)\end{array}$ \\
\hline$\theta_{3}$ & $\begin{array}{c}0.0541 * \\
(2.87)\end{array}$ & $\begin{array}{c}0.0669 * \\
(3.46)\end{array}$ & $\begin{array}{c}0.0859 * \\
(3.89)\end{array}$ \\
\hline$\lambda$ & $\begin{array}{c}0.5798 * * * \\
(1.987)\end{array}$ & $\begin{array}{c}0.6973 * * * \\
(1.876)\end{array}$ & $\begin{array}{c}0.8469 * * * \\
(1.967)\end{array}$ \\
\hline \multicolumn{4}{|l|}{ Variance Equation } \\
\hline$\alpha_{0}$ & $\begin{array}{c}0.00121 * \\
(2.13)\end{array}$ & $\begin{array}{c}0.00369 * * \\
(2.09)\end{array}$ & $\begin{array}{c}0.00497 * * \\
(2.71)\end{array}$ \\
\hline$\alpha_{1}$ & $\begin{array}{c}0.2987 * \\
(3.89)\end{array}$ & $\begin{array}{c}0.3125^{*} \\
(5.99)\end{array}$ & $\begin{array}{c}0.6987^{*} \\
(4.18)\end{array}$ \\
\hline$\beta_{1}$ & $\begin{array}{l}0.8849 * \\
(11.579)\end{array}$ & $\begin{array}{c}0.9498 * * \\
(17.697)\end{array}$ & $\begin{array}{c}0.9767 * * * \\
(20.871)\end{array}$ \\
\hline$\gamma_{1}$ & $\begin{array}{c}0.0124^{*} \\
(1.26)\end{array}$ & $\begin{array}{c}0.00412^{*} \\
(1.57)\end{array}$ & $\begin{array}{c}0.02497^{*} \\
(1.34)\end{array}$ \\
\hline Log Likelihood & 1754.63 & 1759.76 & 1762.65 \\
\hline Ljung-Box Q (12) & $\begin{array}{c}86.978 * \\
(0.000)\end{array}$ & $\begin{array}{c}96.769 * \\
(0.000)\end{array}$ & $\begin{array}{c}97.693 * \\
(0.000)\end{array}$ \\
\hline Ljung-Box $Q^{2}(12)$ & $\begin{array}{c}0.023 \\
(0.000)\end{array}$ & $\begin{array}{c}0.685 \\
(0.000)\end{array}$ & $\begin{array}{c}0.896 \\
(0.000)\end{array}$ \\
\hline
\end{tabular}

Source: Author's calculation

Notes: ${ }^{* * * * * *}$ indicates significance level at $1,5 \& 10$ percent, respectively.

The BSE risk-return tradeoff estimation on monthly return is shown in table 4. The conditional volatility is statistically significant at 10 percent level for all the models, which reveals strong relationship in risk-return for the market. The mean equation based three lags $(\theta 1, \theta 2$ and $\theta 3)$ values are statistically significant at 1 percent, which reveals that the past values have significant impact on the current returns. The $\gamma_{1}$ value in the variance equation is statistically significant at 1 percent level for all the model, which further enhances that the monthly return of BSE are unequal effect of positive and negative innovations. In the variance equation, the values of $\alpha 0, \alpha 1, \beta 1$ are found statistically significant at 1,5 and 10 percent for all the models. Further, the result of Ljung-Box statistics found that in 12-th order the serial autocorrelations are found 
Towards Excellence: An Indexed, Refereed \& Peer Reviewed Journal of Higher Education / Dr.

\section{Ritesh Patel / Page 556-566}

significant at 1 percent level for all the models. The results of Log Likelihood and LjungBox test found the data fit for the model. The Log Likelihood value is higher in the CGARCH $(1,1)$ as compare to other models. The CGARCH $(1,1)$ captures the asymmetric volatility effect and the BSE volatility tends (on monthly basis) to increase and decrease in bad and good news, respectively. The results reveals string and positive risk-return relationship in the BSE market with respect to monthly returns.

\section{- Annual return based estimation of risk-return tradeoff}

Table 5

BSE Risk-return tradeoff estimation on Annual return

\begin{tabular}{|l|c|c|c|}
\hline Particulars & GARCH-M & EGARCH-M & CGARCH (1,1) \\
\hline Mean equation & $0.0009^{*}$ & $0.0001^{*}$ & $0.0018^{* *}$ \\
$\mathrm{C}$ & $(1.45)$ & $(1.99)$ & $(2.09)$ \\
\hline$\theta_{1}$ & $0.1707^{*}$ & $0.1946^{*}$ & $0.2086^{*}$ \\
& $(8.07)$ & $(9.59)$ & $(10.19)$ \\
\hline$\theta_{2}$ & $0.071)^{*}$ & $0.0607^{*}$ & $0.0521^{*}$ \\
& $(1.59)$ & $(1.75)$ & $(1.87)$ \\
\hline$\theta_{3}$ & $0.8731^{*}$ & $0.8964^{*}$ & $0.9877^{*}$ \\
& $(2.01)$ & $(2.20)$ & $(2.29)$ \\
\hline$\lambda$ & $0.6123^{*}$ & $0.7007^{*}$ & $0.8197^{*}$ \\
& $(1.456)$ & $(1.569)$ & $(1.759)$ \\
\hline Variance Equation & & & \\
\hline$\alpha_{0}$ & $0.0119^{*}$ & $0.0199^{*}$ & $0.0234^{*}$ \\
& $(2.03)$ & $(1.89)$ & $(2.24)$ \\
\hline$\alpha_{1}$ & $0.2159^{*}$ & $0.2569^{*}$ & $0.4096^{*}$ \\
& $(2.09)$ & $(3.89)$ & $(3.19)$ \\
\hline$\beta_{1}$ & $0.9015^{*}$ & $0.9120^{*}$ & $0.9737^{*}$ \\
& $(8.596)$ & $(10.597)$ & $(12.459)$ \\
\hline$\gamma_{1}$ & $0.007^{*}$ & $0.0044^{*}$ & $0.0189^{*}$ \\
& $(1.10)$ & $(1.32)$ & $(1.43)$ \\
\hline Log Likelihood & 1901.89 & 1925.96 & 1927.95 \\
\hline Ljung-Box Q (12) & $86.896^{*}$ & $95.896^{*}$ & $97.597^{*}$ \\
& $(0.000)$ & $(0.000)$ & $(0.000)$ \\
\hline Ljung-Box Q ${ }^{2}(12)$ & 0.156 & 0.199 & 1.125 \\
& $(0.000)$ & $(0.000)$ & $(0.000)$ \\
\hline
\end{tabular}

Source: Author's calculation

Notes: $*, * *$ indicates significance level at 1 and 5 percent, respectively.

Table 5 shows the BSE Risk-return tradeoff estimation on annual return series. The conditional volatility is statistically significant at 1 percent for all the models, which reveals positive and strong risk-return relationship. The values of the thee lags $(\theta 1, \theta 2$ 
and $\theta 3$ ) of the mean equation are statistically significant at 1 percent, which reveals that the past values have significant impact on the current returns. In the variance equation, the value of $\gamma_{1}$ is significant at 1 percent level for all the models, which further reveals that the return shows the unequal effect of positive and negative innovations. Further, the values of $\alpha 0, \alpha 1, \beta 1$ are found statistically significant at 1 percent level for all the models. The result of Ljung-Box statistics found that in 12-th order the serial autocorrelations are found significant at 1 percent level for all the models. The high value of Log Likelihood for the CGARCH $(1,1)$ model over other two models found that the data fits best in the CGARCH $(1,1)$ as compare to others. The CGARCH $(1,1)$ captures the asymmetric volatility effect and the BSE volatility tends to increase and decrease in bad and good news, respectively. The result reveals strong, positive and statistically significant riskreturn relationship for annual returns.

On comparing the risk-return tradeoff results of daily, monthly, and annual return series few inference are drawn.

1) In the daily return series the risk-return relationship is weaker. However the relationship is stronger in the monthly, and annual returns. As compare to other frequency period, the annual return shows positive and stronger risk-return relationship. The riskreturn relationship is stronger in the longer period as compare to short-term time period.

2) The data fits best in the CGARCH $(1,1)$ as compare to GARCH-M and EGARCH-M. The CGARCH $(1,1)$ model can captures the asymmetric volatility effect for all the different frequency based returns. The market volatility can be responded by decreasing or increasing to the bad or good news, respectively.

3) The values of the thee lags $(\theta 1, \theta 2$ and $\theta 3)$ of the mean equation are statistically significant at different level for all the return series. Hence, the past values have significant impact on the current returns for all the different frequency returns. The significant coefficient of the mean equation can help in predicting the market return.

4) The different return series exhibit the asymmetric volatility effect.

\section{Conclusion and Implications}

The objective of the present study is to explore the risk-return relationship in the Indian stock market. The study is performed on the BSE covering a sample period from January 4, 2000 to March 30, 2020. The study is carried out using daily, monthly, and annual data. The risk-return relationship is examined using the GARCH-M, EGARCH-M and CGARCH $(1,1)$ model.

The descriptive statistics revealed that the return is increasing with the increase in the risk. The conditional volatility is positive but statistically insignificant for all the models, which reveals weak positive relationship in risk-return for the market in the daily return series. But the conditional volatility is statistically significant for all the models for 


\section{Ritesh Patel / Page 556-566}

monthly, and annual return series. This reveals strong risk-return relationship for the market. Except the daily return, in all other return series, the market has witnessed strong and positive risk-return tradeoff. As compare to other frequency period, the annual return shows positive and stronger risk-return relationship. The BSE shows stronger and positive risk-return relationship in the longer period as compare to short-term time period. Further, as the period increases the risk-return relationship becomes more positive and stronger.

The outcome of the Log Likelihood reveals that as compare to GARCH-M and EGARCH-M, the CGARCH $(1,1)$ has better capacity to fit the data. As a result, the CGARCH $(1,1)$ captures the asymmetric volatility effect for all the different frequency based returns. The market volatility increases with the bad news and decreases with the good news. The three lag values of the mean equation are statistically significant for all the models. The past values makes significant impact on the current return \& can help to predict the future return of the market. Further, the different return series exhibit the asymmetric volatility effect.

Based on the outcome, few implications are drawn for the investors. First, the risk-return relationship is stronger and significant in longer duration of the investment. Hence, the investors should design their investment plan by considering the time horizon. Second, the results of descriptive statistics proves the theory of higher the return, higher the risk. The Investors should design their investment strategy by considering the risk-return mechanism. Third, the different return series has different volatility asymmetric effect, that is, market volatility increases with the bad news and decreases with the good news. Hence, the investors can make their investment decision by considering the volatility effect with respect to flow of news in the market. Fourth, the study provides the measure for the dependence of the market return. Hence, the market efficiency can be raised to get better results of the market return. 


\section{Ritesh Patel / Page 556-566}

\section{Works Cited}

Aslanidis, N., Christiansen, C., \& Savva, C. S. (2016). Risk-return trade-off for European stock markets. International Review of Financial Analysis, 46, 84-103.

Bagchi, D. (2012). Cross-sectional analysis of emerging market volatility index (India VIX) with portfolio returns. International Journal of Emerging Markets. 7 (4), 383-396.

Bali, T. G., Cakici, N., \& Tang, Y. (2009). The conditional beta and the cross-section of expected returns. Financial Management, 38(1), 103-137.

Bollerslev, T., Chou, R. Y., \& Kroner, K. F. (1992). ARCH modeling in finance: A review of the theory and empirical evidence. Journal of econometrics, 52(1-2), 5-59.

Bollerslev, T., Engle, R. F., \& Wooldridge, J. M. (1988). A capital asset pricing model with time-varying covariances. Journal of political Economy, 96(1), 116-131.

Cheng, A. R., \& Jahan-Parvar, M. R. (2014). Risk-return trade-off in the pacific basin equity markets. Emerging Markets Review, 18, 123-140.

Conrad, J., Dittmar, R. F., \& Ghysels, E. (2013). Ex ante skewness and expected stock returns. The Journal of Finance, 68(1), 85-124.

Dickey, D. A., \& Fuller, W. A. (1979). Distribution of the estimators for autoregressive time series with a unit root. Journal of the American statistical association, 74(366a), 427-431.

Dickey, D. A., Bell, W. R., \& Miller, R. B. (1986). Unit roots in time series models: Tests and implications. The American Statistician, 40(1), 12-26.

Engle, R. F., \& White, H. (1999). Cointegration, causality, and forecasting: a Festschrift in Honour of Clive WJ Granger. Oxford University Press on Demand.

Ghysels, E., Santa-Clara, P., \& Valkanov, R. (2005). There is a risk-return trade-off after all. Journal of Financial Economics, 76(3), 509-548.

Glosten, L. R., Jagannathan, R., \& Runkle, D. E. (1993). On the relation between the expected value and the volatility of the nominal excess return on stocks. The journal of finance, 48(5), 1779-1801.

Gujarati, D. N. (2013). Basic econometrics, Fifth Edition, Tata McGraw-Hill Education. Hamilton, J. D. (1994). Time Series Analysis. Princeton University Press, Princeton, New-Jersey.

Merton, R. C. (1973). An intertemporal capital asset pricing model. Econometrica: Journal of the Econometric Society, 41(5), 867-887.

Pettengill, G. N., Sundaram, S., \& Mathur, I. (1995). The conditional relation between beta and returns. Journal of Financial and quantitative Analysis, 30(1), 101-116. 
Towards Excellence: An Indexed, Refereed \& Peer Reviewed Journal of Higher Education / Dr. Ritesh Patel / Page 556-566

Phillips, P. C., \& Perron, P. (1988). Testing for a unit root in time series regression. Biometrika, 75(2), 335-346.

Roll, R., \& Ross, S. A. (1994). On the cross-sectional relation between expected returns and betas. The journal of finance, 49(1), 101-121.

Terregrossa, S. J., \& Eraslan, V. (2016). An analysis of the relation between return and beta for portfolios of Turkish equities. Cogent Economics \& Finance, 4(1), 1168501.

$\mathrm{Wu}$, L. (2018). Estimating risk-return relations with analysts price targets. Journal of Banking \& Finance, 93, 183-197.

\section{Dr. Ritesh Patel Assistant Professor, Economics and Finance area Institute of Management, Nirma University, India. \\ Email id: ritesh@nirmauni.ac.in}

